\title{
Initial physical education students' beliefs about sport teaching
}

\author{
Jeferson Rodrigues de Souza \\ Federal University of Santa Catarina, Brasil \\ jefersonrsouza@hotmail.com \\ Valmor Ramos \\ State University of Santa Catarina, Brasil \\ valmor.ramos@udesc.br \\ Vinicius Zeilmann Brasil \\ Federal University of Santa Catarina, Brasil \\ vzbrasil@hotmail.com \\ Filipy Kuhn \\ Federal University of Santa Catarina, Brasil \\ filipykuhn@hotmail.com \\ Ana Flávia Backes \\ Federal University of Santa Catarina, Brasil \\ anafbackes@hotmail.com \\ Ciro Goda \\ State University of Santa Catarina, Brasil \\ gohda.ciro@gmail.com \\ Leonardo Ristow \\ State University of Santa Catarina, Brasil \\ leonardoristow@live.com \\ Bárbara Cardoso Conti \\ State University of Santa Catarina, Brasil \\ ba_jagua@hotmail.com
}

Cita sugerida: Rodrigues, J., Ramos, V., Brasil, V. Z., Kuhn, F., Backes, A. F., Goda, C., Ristow, L. y Conti, B. C. (2018). Initial physical education students' beliefs about sport teaching. Educación Física y Ciencia, 20(3), e052. https://doi.org/10.24215/23142561e052

Recibido: 28 marzo 2018 - Aceptado: 19 junio 2018 - Publicado: 27 julio 2018

(c) (i)(5) (2) Esta obra está bajo licencia Creative Commons Atribución-NoComercial-CompartirIgual 4.0 Internacional cc) 


\title{
Initial physical education students' beliefs about sport teaching
}

Creencias de estudiantes de educación física para enseñanza del deporte

\author{
Jeferson Rodrigues de Souza \\ Federal University of Santa Catarina, Brasil \\ jefersonrsouza@hotmail.com \\ Valmor Ramos \\ State University of Santa Catarina, Brasil \\ valmor.ramos@udesc.br \\ Vinicius Zeilmann Brasil \\ Federal University of Santa Catarina, Brasil \\ vzbrasil@hotmail.com \\ Filipy Kubn \\ Federal University of Santa Catarina, Brasil \\ filipykuhn@hotmail.com \\ Ana Flávia Backes \\ Federal University of Santa Catarina, Brasil \\ Ciro Goda \\ State University of Santa Catarina, Brasil \\ Leonardo Ristow \\ State University of Santa Catarina, Brasil \\ Bárbara Cardoso Conti \\ State University of Santa Catarina, Brasil \\ ba_jagua@hotmail.com
}

\begin{abstract}
:
The objective of this study was to analyze the beliefs of undergraduates about the strategies for teaching sports at the beginning of their Bachelors degree in Physical Education at a public university in Southern Brazil. A qualitative, descriptive and interpretive research approach was adopted through multiple case studies. Eight bachelor students in Physical Education participated in the study. To collect the data, we used a combination of structured and semi-structured interview procedures, systematic observation, and memory stimulation. Content analysis was used from categories determined a priori. The results indicated that the students have beliefs that favor strategies focused on analytical learning tasks, verbal management interventions, prescriptive pedagogical feedbacks, and positive evaluations. These beliefs were developed mainly through personal practical experiences in competitive sports as well as through observation of coaches or teachers and verbal orientations received from coaches and peers. The undergraduates' beliefs about teaching strategies represent a particular conceptual model, with structures similar to directive teaching models. Thus, we conclude that the prolonged contact of the undergraduates with various learning situations in sports contributed to the memorization of concepts, values, and teaching behaviors, which enabled and conditioned the construction of one own model of teaching sports.
\end{abstract}

KeYwORDS: Beliefs, Teaching, Sports. 


\section{Resumen:}

El objetivo de este estudio fue analizar las creencias de los estudiantes de Educación Física de una universidad pública brasileña, acerca de las estrategias para la enseñanza de los deportes. Se realizó una investigación cualitativa, descriptiva e interpretativa con procedimientos de estudio de casos múltiplos de ocho estudiantes de licenciatura en Educación Física. Los datos fueron obtenidos por medio de la combinación de procedimientos de entrevista, observación sistemática y estimulación de la memoria. Para el análisis de contenido se utilizó categorías determinadas a priori. Los resultados indicaron que los estudiantes presentaron creencias que favorecen estrategias enfocadas en tareas analíticas de aprendizaje, intervenciones verbales de manejo de clase, feedbacks pedagógicos prescriptivos y evaluativos positivos. Estas creencias se desarrollaron a través de experiencias prácticas personales en deportes competitivos, la observación de entrenadores o maestros, y en las orientaciones verbales recibidas de entrenadores y compañeros. Las creencias de los estudiantes retratan un modelo conceptual particular, con estructuras similares a los modelos de enseñanza directiva. Se concluyó que el contacto prolongado de los estudiantes en situaciones de aprendizaje en los deportes contribuyó a la memorización de conceptos, valores y comportamientos de enseñanza, condicionando la construcción de su modelo personal de enseñanza de los deportes.

Palabras Clave: Creencias, Enseñanza, Deportes.

\section{INTRODUCTION}

Studies with teachers in training show that even before joining the university people spend about 13,000 hours as apprentices during their school life, observing their teachers teaching. These experiences obtained in an educational environment become memories and seem to influence the choice of profession and personal engagement throughout ones professional life (Tsangaridou, 2006). Within the context of sports, studies show that coaches participate on average between 3000 and 6000 hours in sports or as athletes, before entering a professional career in sports (Gilbert, Côté, \& Mallett, 2006).

The experiences prior to becoming professionals, therefore, becomes a set of personal beliefs and creates a particular understanding of how to teach and learn (Pajares, 1992; Richardson, 1996). These beliefs can be identified as individual actions or routine procedures, useful for pedagogical intervention, even if they are scientifically fragile or conceptually incoherent among the used strategies (Fives, Lacatena, \& Gerard, 2015).

The value of this cognitive construct has directed research related to the teachers' thinking paradigm, in the sense of trying to describe the process of learning and changes that occur in the teachers' minds during the time they are learning to become professionals. The perspective is that learning stems from an ongoing process of reconstructing beliefs, and that new knowledge can only be assimilated and organized from a set of pre-existing beliefs (Fives \& Buehl, 2012; Kagan, 1992; Pajares, 1992; Posner, Strike, Hewson, \& Gertzog, 1982; Richardson, 2003; Skott, 2015).

In the area of Physical Education, research on beliefs has frequently used qualitative procedures to investigate the purposes of teaching or a teacher's curricular goals, teaching strategies, contents to be taught, the understanding of the learning process, and the epistemological aspects of the learning process taught throughout their careers. The studies recommend conducting research that identifies the previous beliefs of future teachers when initially entering training programs, in order to verify the level of knowledge about teaching and learning, as well as to give personal meanings to their own process of learning how to teach throughout their career (Adamakis \& Zounhia, 2016; Bernstein, Herman, \& Lysniak, 2013; Kulinna, Brusseau, Ferry, \& Cothran, 2010; Lodewyck, 2015; Ní Chróinín \& O’Sullivan, 2016; Ramos, Souza, Brasil, Barros, \& Nascimento, 2014; Randall \& Maeda, 2010; Souza, Brasil, Kuhn, Barros, \& Ramos, 2017). Moreover, it is important to investigate how these beliefs interfere with teachers' pedagogical practices and how training programs impact the process of acquiring teaching knowledge (Philpot \& Smith, 2011; Sofo, Beard, Slattery, \& Howard, 2012).

Thus, the purpose of this study considers the need to understand how teaching beliefs are created and structured, how they interfere in the pedagogical practices of undergraduates in the initial stages of their degree, and how these beliefs influence the process of (re)constructing teaching knowledge during their undergraduate degree. Therefore, the objective of this study was to analyze the beliefs of undergraduate 
students majoring in Physical Education at a public university in Southern Brazil on how to teach sports. Specifically, the objective was to verify their beliefs on teaching strategies associated with their previous personal experiences.

\section{METHOD}

\section{Type of Research}

The study used a descriptive and interpretive qualitative research approach that allows the description and interpretation of significant aspects of the information provided from those investigated, considering the nature of the context and the sociocultural processes involved in the construction of the data (Denzin \& Lincoln, 2008). Multiple case study procedures were also adopted to describe and analyze each participant, as well as to compare the regularities and specificities of each participant's information (Yin, 2010).

\section{Participants}

Eight first-year undergraduate students obtaining a bachelors degree in Physical Education and enrolled in a public university in Southern Brazil participated in the study. The subjects were intentionally selected to meet the following inclusion criteria: a) enrolled regularly in the second semester of the undergraduate course; b) attending a specific class for the initiation to pedagogical processes in sports; c) does not have previous teaching experience as a teacher or sports coach, with the purpose of characterizing beliefs based on personal experiences prior to beginning the undergraduate course; and d) expresses motivation and willingness to participate in the study. Based on the adopted criteria, the participants were selected during three different semesters to have the largest possible number of participants, four subjects were selected in the first semester of 2015 , three in the second semester of 2015, and one in the first semester of 2016.

\section{Tools and Data Collection}

Data collection took place in three stages and was a combination of interview procedures and systematic observation. The first stage consisted in collecting data during the first week of the previously mentioned class. In front of the class, the researcher provided clarifications on the objectives and procedures of the research and requested that all students complete an individual structured interview script, in order to identify personal and professional experiences within the sports context up until the time of the research. The researcher then invited those who met the inclusion criteria to participate in the study.

The research volunteers signed a Term of Free and Informed Consent, authorizing the recording and dissemination of results. Immediately after, the researcher asked the subjects to prepare a lesson plan to teach a sport of their choice. The researcher provided no information on planning, content, methodologies, and other pedagogical procedures. The plan, therefore, was prepared individually without any consultation, under the supervision of the researcher, in order for the participants to explore their own memories of teaching.

During the second stage, systematic observation procedures were used from the image and audio recording of the teaching sessions, from a simulated situation in which the selected participants implemented their lesson plans in a teaching session for their classmates. The recording equipment was placed at a distance from the interactive teaching environment to avoid interference in the participants' actions. The entire teaching session and space was captured by digital camera. 
Simultaneously, the participants' verbal interventions were captured using a digital voice recorder and lapel microphone. The images and audios were stored and edited using the program Movie Maker and Windows Media Player. The verbal interventions were verbatim transcribed and stored in a microcomputer with the aid of Microsoft Office Word 2007.

During the last stage, a semi-structured interview was conducted with seven questions about the personal experiences of the participants within the sports context. A second interview was conducted as a memory stimulation procedure, with 12 questions regarding their pedagogical beliefs (purposes, contents, strategies, learning process) seen in the recording of the teaching sessions, as well as their respective sources of learning.

The same researcher conducted the interviews individually with each participant in a classroom at the teaching institution, previously determined according to the convenience of the interviewees. The procedures of memory stimulation consisted in presenting the images and audio of the teaching session on a computer screen, at the same time the researcher stimulated participants to remember the teaching situations, to justify their pedagogical procedures, and also the sources of learning that contributed to achieving such an understanding about how to teach sports. In order to develop these research procedures and guide the researcher's questions, a previous analysis of the images of each teaching session was conducted, aiming to identify and classify the learning tasks, contents, and verbal interventions. The information obtained through the semi-structured interviews was captured and stored through a digital voice recorder and transcribed verbatim using Microsoft Office Word 2007.

The present study was approved by the Ethics Committee in Research with Human Beings at a public university in the State of Santa Catarina, Brazil (Registration no. 83238/2012). The anonymity of the participants was preserved through the combination of letters and numbers (from G1 to G8) to describe the information provided by each participant.

\section{Data Analysis}

We analyzed the data from the learning tasks and verbal interventions implemented by each subject in the stimulated teaching sessions. The learning tasks were analyzed according to the duration of recorded procedures, which consisted in counting the time the tasks were implemented during the sessions. For the verbal interventions, we registered occurrences to verify the frequency of instructions used by the participants in the interactive period of the teaching session (Siedentop, 1998).

To characterize and classify the types of learning tasks, we used the Ticó-Camí (2002) proposal to name the tasks: analytical (AN), which correspond to a type of task where repetitive motor skills training prevails isolated from the context of the game; synthetic (SI), which corresponds to reduced situations in the condition of inferiority/ superiority/ numerical equality of players, maintaining some elements of the formal game structure; and global (GL), which correspond to the formal game or game with modification, but without significant changes in relation to the structural characteristics.

For each type of task, the Rink (1993) progression model was used to analyze the specific contents and conditions of the tasks, namely: 1) simple skills without opposition (HSSO);2) a combination of skills without opposition (CHSO). For the global tasks we used classifications contained in the protocol developed by Stefanello (1999) and adapted by Saad (2002, 2012), specifically: a) recreational game (JREC), characterized as a game for recreation purposes, and in some cases may stimulate the development of tactical aspects; b) conditioning game (JCDC), which consists of developing specific situations of attack and defense present in the formal game, with the intention of repeating such circumstances several times; c) reduced game (JRED), which refers to a type of game that reduces the complexity and potentiates situational contexts by modifying spaces or number of players.

In order to classify the verbal interventions issued by the subjects, we used Sarmento (2004) categorization of pedagogical feedbacks as a basis: evaluative feedback (FA+, FA-), which consists in giving simple judgment 
or appraisal of the execution of the task without reference to its form; descriptive feedback (FD), which describes how the task was performed; prescriptive feedback (FP), which provides information on how the task should be conducted; and interrogative feedback (FI), which consists of asking questions about the task performed, encouraging the students to reflect on the mistakes made or the correct execution. Furthermore, we also considered verbal interventions from the teaching session (GT) related to resource management (time, students, space, and materials).

The data contained in the interview transcripts and observations were analyzed using the Content Analysis technique (Bardin, 2011), with categories determined a priori. The analysis process was conducted in three phases: a) organization of information regarding planning of undergraduate students, transcription of interviews, and observations; b) the material was explored, in which the transcripts were coded for content representations, identifying the units of meaning according to the categories of analysis; $\mathrm{c}$ ) we verified the frequencies of the units of meaning for each participant. In order to manage the data, we used the qualitative analysis program QSR Nvivo, version 9.2.

Lastly, we checked data with participants to ensure the credibility and reliability of the information; each participant analyzed the videos and transcripts of the interviews to confirm the accuracy of the data. Moreover, a review was conducted by two researchers with qualitative research experience, who analyzed the same data set, and compared their interpretations, and did not identify discrepancies among them (Maxwell, 2005; Sparkes \& Smith, 2014).

\section{Results}

\section{Learning Tasks}

We found that undergraduates have chosen to teach the sports modalities in which they have gained some previous personal practice and experience. Specifically, G1 and G3 chose to teach Volleyball because of their experiences in sports training and recreational sports practice, respectively. In the case of G2, his previous experience was in the recreational practice of Baseball. The undergraduates G4, G6, G7, G8, taught futsal based on their experiences in sports training. Sport's training was also why G5 taught Rugby.

According to Table 1, the time records of the learning tasks indicated that all the participants adopted analytical tasks (AN) in the teaching sessions/classes, and most of them also used global tasks (GL) (G1, G3, G4, G5, G6, G8). On the other hand, there is a lack of synthetic tasks (SI) in all the teaching sessions.

Table 1 - Time of learning tasks used in the undergraduates' teaching sessions.

\begin{tabular}{llllll}
\hline \multicolumn{6}{l}{ Teaching strategies for learning tasks de - minutes (\%) } \\
\hline \multirow{2}{*}{ Grad. } & \multicolumn{1}{l}{ Analytical Tasks (AN) } & \multicolumn{2}{l}{ Global Tasks (GL) } & \\
\cline { 2 - 6 } & HSSO & CHSO & JREC & JRED & JF \\
\hline G1 & - & $9.8(69.5 \%)$ & - & - & $4.3(30.5 \%)$ \\
\hline G2 & $14.4(88 \%)$ & $2(12 \%)$ & - & - & - \\
\hline G3 & $8.3(49 \%)$ & $1.9(11 \%)$ & - & - & $6.8(40 \%)$ \\
\hline G4 & - & $15.9(83 \%)$ & - & - & $3.2(17 \%)$ \\
\hline G5 & - & $4(14 \%)$ & $15.6(55.5 \%)$ & $8.5(30.5 \%)$ & - \\
\hline G6 & $7.8(30.5 \%)$ & $15.5(61 \%)$ & - & - & $2.2(8.5)$ \\
\hline G7 & $1.2(12.5 \%)$ & $8.5(87.5 \%)$ & - & - & - \\
\hline G8 & $2.1(9.5 \%)$ & $11.3(51 \%)$ & - & - & $8.8(39.5 \%)$ \\
\hline
\end{tabular}

Source: Author.

Note: Grad. = Undergraduates; $\mathrm{AN}=$ Analytical; GL = Global; $\mathrm{HSSO}=$ Simple skills without opposition; $\mathrm{CHSO}=$ Combination of skills without opposition; JREC = Recreational game; JRED = Reduced game; JF = Formal game. 
For the analytical tasks, we found that some participants (G1, G4, G6, G7, G8) prioritized tasks that combined two or more technical skills without the opposition of opponents, and the participants (G2, G3) prioritized the use of simple technical skills without the opposition of opponents. For global tasks, most of the participants (G1, G3, G4, G6, G8) prioritized formal game tasks (JF), usually after practicing analytical tasks, determining that the teaching sequence was through the exercise of analytical tasks, followed by formal play. In the particular case of G5, the global tasks were used in recreational games (JREC) and reduced games (JRED), a sequence different from the others.

To justify the use of analytical learning tasks, the undergraduates have stated that these are the most appropriate forms of exercise for the teacher or coach to prioritize when teaching sports (G1, G2, G3, G4, G6, G7, G8), in order to improve the elementary technical skills of the sport, as indicated by G7:

It is through repetition that movement improves, to see how it is and how it is done. You look at the movement and do it, one at a time, every five seconds you are doing it one more time and trying to better the movement that is new to you, like the bridge (a specific goalie movement) that for some people is new, so you repeat it a lot (G7).

Thus, participants understand that teaching "in pieces" (G1) or in fragmented ways simplifies the learning process in relation to technical skills (G1, G2, G4, G6, G8), in order to stimulate the relationship of the learner to the ball. Furthermore, they believe that this way of teaching allows the teacher or coach to have greater "control" (G2) of the behavior and motor execution of the students, that is, it promotes a learning context with easy organization to carry out the necessary pedagogical interventions with greater focus on technique (G2, G4, G7, G8), as G4 states:

I think mainly this type of exercise (analytical), like this one, is a very simple form of organization, this is how I see their level, I think it would fit well. [...] Also, it's easier for me to control the class, it's easier for me to see faults, because when I'm in the middle, it gets easier, especially when they're in lines and it's extremely easy to work like that, see errors, hits, and everything else (G4).

When asked about another type of activity to teach, or dealing specifically with global tasks, the participants emphasized the relevance of using these forms of exercise, especially formal play at the end of sessions, to promote a fun or leisure situation for students (G1, G3, G4, G5, G7 and G8). As stated by G3: "The game is to distract the people, they like to play. If I was going to be just giving technique, I think they would not like it very much".

The undergraduates also reported that this type of activity provides the learner with the integration of all the developed technical skills (G1, G2, G4 and G6), or specifically: "join all that has been learned" (G1). Additionally, some of them pointed out that global tasks serve to apply learned skills to the game (G1, G2, G6, G7 and G8), as reported by G6: "I'd rather give first, say, a base for the students to do alone, try to make the movement, and then try to integrate that into the game itself, in a more real situation".

In the particular case of G5, favoring global tasks and modifying game structures to teach sports was intended to "arouse people's interest," as opposed to those more analytical exercises for the development of motor skills. Thus, he believes that the use of these games stimulates the engagement and raises the motivation of the students during learning, mainly in function of liveliness, as he himself states:

So I thought I could do these activities, those games that are much more interesting, and in the middle there I put the pass and receive similar to the training. [...] But this way of playing is an easy and fun way to learn, because if I do a very focused training for some special skill as you train it can become very monotonous and people end up not interested at all (G5). 


\section{Verbal Interventions}

From the analysis of the participants' verbal interventions, we found that the instructions were focused on session management (G2, G3, G5, G6, G7 and G8). Participants also used prescriptive pedagogical feedbacks and positive evaluative pedagogical feedbacks during interventions, as shown in Table 2.

Table 2 - Frequency of verbal interventions used in the undergraduates' teaching sessions.

\begin{tabular}{|c|c|c|c|c|c|c|}
\hline \multicolumn{7}{|c|}{ Teaching strategies for verbal interventions- frequency (\%) } \\
\hline \multirow{2}{*}{ Grad. } & \multicolumn{6}{|c|}{ Types of verbal interventions } \\
\hline & GT & FA+ & FA- & FD & FP & FI \\
\hline G1 & $21(23.5 \%)$ & $19(21 \%)$ & - & $3(3.5 \%)$ & $46(51 \%)$ & $1(1 \%)$ \\
\hline G2 & $39(38 \%)$ & $23(22.5 \%)$ & - & $10(10 \%)$ & $29(28.5 \%)$ & $1(1 \%)$ \\
\hline G3 & $28(56 \%)$ & $3(6 \%)$ & - & - & $19(38 \%)$ & - \\
\hline G4 & $19(20 \%)$ & $27(28.4 \%)$ & - & $4(4.2 \%)$ & $45(47.4 \%)$ & - \\
\hline G5 & $75(62 \%)$ & $17(14 \%)$ & - & $8(6.5 \%)$ & $21(17.5 \%)$ & - \\
\hline G6 & $51(47.5 \%)$ & $25(23.5 \%)$ & $1(1 \%)$ & - & $30(28 \%)$ & - \\
\hline G7 & $32(41 \%)$ & $23(29.5 \%)$ & $1(1.5 \%)$ & $5(6.5 \%)$ & $17(22 \%)$ & - \\
\hline G8 & $28(52 \%)$ & $17(31.5 \%)$ & - & $2(3.5 \%)$ & $7(13 \%)$ & - \\
\hline
\end{tabular}

As for management instruction (GT), the undergraduates emphasized that this way of intervening helps the teacher or coach maintain the practice of learning activities with a high level of organization (G1, G2, G3, G4, G6, G7, and G8). This ensures the achievement of the pre-established objectives of the lesson, as stated by G4: "this class format, I think this management is very important, especially when the student does not have much awareness and notion, because if they are performing the exercises, I think it is important to organize the situation a little for them to learn".

In addition to organizing the learning context, G5 stated that another purpose for focusing on managing instructions is how to teach values and modes of conduct to develop "respect". Moreover, this also helps in the recognition and acceptance of decisions made by coaches, teachers, and/or referees during the practice of sports.

For prescriptive pedagogical feedbacks (FP), all participants believe that this form of instruction is useful for correcting students' technical mistakes during learning tasks. This correction has the intent of informing the correct way to perform the motor skill (G1, G2, G3, G4, G5, G6, G7 and G8), as stated by G3:

Because if you try to show how the technique is done, you can help the student to do it. Because there is a right way to do it, maybe I do not know exactly what it is, but I know there is a right way. So I guess when you have the knowledge of how this should be done, it will be easier for the student to be able to do it (G3).

In regards to positive evaluative feedbacks (FA+), most of the participants (G1, G2, G3, G4, G5, G6 and G8) indicated that this type of instruction raises the motivation of students during motor tasks. The participants recognized this as a way of "praising" and also informing the student that they are on the "right path", thus, stimulating the self-assessment of one's own learning as found in G4's dialogue: "I think mainly because of the motivational aspect, and the second point is that the student is able to evaluate himself. For example, when I praise them after the set-up, I think the student can evaluate themselves afterwards". 


\section{Discussion}

In this study, we found that the subjects entered university with a belief system about teaching strategies based on the preponderant use of analytical learning tasks, with the application of global tasks, followed by verbal interventions focused on management, the use of prescriptive and positive evaluative feedback, as well as prioritizing the development of motor skills. Moreover, we found that the personal experience of the undergraduates impacted the development of these beliefs, especially those obtained through sports training.

Therefore, we believe that undergraduates entered the course with a set of beliefs or "model of action," as Calderhead (1988) suggests, with structural characteristics similar to a direct teaching model. Teaching with this perspective is characterized by the use of pedagogical strategies that emphasizes meticulous control of learning situations, commonly used to develop motor skills, especially with the use of prescriptive feedback (Metzler, 2000).

These findings are similar to results found by Tsangaridou (2008), who investigated two future generalist preservice teachers during the earliest formal teaching experiences at the outset of the complementary pedagogical training course in Physical Education at a university in Cyprus. The results showed that the teachers believed that teaching should contemplate learning tasks with progressions until they reached the modified games. Moreover, they also stated that instructional strategies should be more direct, with a focus on effective classroom management and good social relations between teacher and student. One of the participants, however, acknowledged that an indirect instruction stimulates critical thinking and cooperative attitudes among learners.

The preferences for a specific instructional model may also be related to the individual's own epistemological beliefs, as found in the research by Lodewyck (2015). This study involved 311 first year and last year undergraduate students majoring in Physical Education at a university in Canada that were participating in academic coursework geared to teaching sports games. Using open and closed questionnaires, the author found that those that believed that knowledge is acquired through direct transmission and memorization, tended to adopt direct instruction models, similar to those that were previously submitted to the university. However, at the end of the course, most participants preferred indirect models of teaching (ex.: Teaching Games for Understanding, Sports Education), recognizing the mediating role of the teacher and the importance of social interactions in the learners path to gaining knowledge.

Excessive concern with aspects of classroom management has been found in studies with future generalist teachers in complementary pedagogical training in Physical Education in the USA. The beginning of the course or the first teaching experiences sought to focus attention on the organization of the classroom environment to achieve its established objectives, without emphasizing the other elements of the learning and teaching process. The authors suggest that there is a tendency for undergraduates to reduce focus on the components of classroom management and turn their attention to teaching content over time. Furthermore, they recommend that classroom management tasks should be explored and discussed from the beginning of training courses, simultaneously raising concerns about content and social relationships in the classroom (Ní Chróinín \& O’Sullivan, 2016).

In qualitative studies, Randall and Maeda (2010), with 54 future generalist teachers at the beginning of a complementary pedagogical training in Physical Education, also found that previous experiences with motor skills, positive or negative, determined beliefs about teaching, adopting or avoiding forms of intervention, and also prioritizing motor content during classes.

When interviewing 12 undergraduate students from New Zealand on the purposes of teaching at the beginning and at the end of the Physical Education course, Philpot and Smith (2011) found that the students already had previous beliefs about teaching, understanding that sports should be the prevailing content in Physical Education classes. In addition, these undergraduates at the beginning of the course showed that 
their beliefs about teaching were shallower compared to the same ones at the end of the course, most likely due to little critical thinking about their own beliefs and professional experiences prior to initial training.

Research by Bernstein, Herman, and Lysniak (2013), with 10 undergraduate students in a class focused on pedagogical practices of competitive games in a Physical Education course in the USA, found that the participants possessed previous beliefs about teaching, sustained by their own personal experiences practicing competitive sports. These previous beliefs were reflected in the use of competitive games in their classes, focusing on the acquisition of motor skills. This style of teaching was found more among university students with greater personal experience in competitive sports. Throughout the course, the authors found that the participants' previous beliefs were recognized as central elements for constructing a personal understanding and particular form of intervention in teaching.

In the Brazilian context, qualitative research in the field of initial training in Physical Education has also found that university students enter teaching training courses with a set of experiences and beliefs about teaching. The latter conditions the choices of new experiences throughout the course, as well as the understanding that sports should be the main themes to be addressed in Physical education classes (Figueiredo, 2008), giving priority to the specific motor skills of the sport (Gariglio, 2011; Ramos, Souza, Brasil, Barros, \& Nascimento, 2014; Souza, Brasil, Kuhn, Barros, \& Ramos, 2017).

According to Figueiredo $(2004,2010)$, the experiences obtained in situations of sports practices can be called "sociocorporal", due to its multidimensional nature, involving not only motor memories, but also affective, cognitive, social, and conceptual dimensions. All of these arise from the interactions between the person practicing and the environment, with implications on personal and professional identity of the Physical Education teacher.

The central and stable character of some beliefs (in a belief system) reflects their level of association with the affective and axiological dimensions (values) of the individual, which is why these beliefs come to characterize or constitute the very identity of the individual. It is because of this aspect that, in part, beliefs have an evaluative and judgmental character, and act as a personal filter, in the sense of perceiving and deciding on what is a priority to make an effort to undertake (Rokeach, 1981).

Previous beliefs, in particular, are anchor ideas and correspond to simpler or superficial personal propositions about a given theme, acting as subordinators of other, more complex concepts in a learning process (Posner, Strike, Hewson, \& Gertzog, 1982). The learning that advocates the modification of one's beliefs or structures of knowledge through the integration of new knowledge, rather than replacing them with new ones, is more meaningful to the teacher in training because it promotes a more consistent change in the individual, and therefore, allows the use of knowledge in future teaching and life situations (Gomes et al., 2008).

These beliefs that undergraduates have when they initially enter their course are referential in their cognitive structure and in their internal logical thinking. This permits undergraduates to interact with similar "signs" contained in strategies used by teachers in the relational classroom environment, as well as with the information or contents available in the environment, thus, assigning personal relevance to the information. It is through confrontation of their structure of knowledge with new information that an individual judges whether the new information is relevant and meaningful to be integrated into their internal structure of thought (Alegro, 2008; Moreira, 2012).

Therefore, the professional training process should be based on pedagogical principles that value the prior knowledge of students as a starting point for new learning, creating contexts that are authentic or very similar to the realities of the future professional. Moreover, it is necessary to provide experiences and practice environments that modify part of or all dimensions (affective, axiological, cognitive, motor) and their relationships present in the previous experiences undergraduates had in childhood and youth. This means that the learning situations in the initial training courses should be adjusted and similar to the nature of those in which they have been created or were created. 
In the scope of initial training in Brazil, there is an appreciation of practical knowledge in the curricula of Physical Education courses. This is due to the increase in hours of pedagogical practice throughout the course, as well as the increase in internship hours beginning in the second half of the course, according to National Curricular Guidelines (Brasil, 2002). However, it is necessary to investigate how this process occurs daily in the classroom of trained teachers.

According to Richardson (2003), the main challenge in teacher training is to help university students understand their own beliefs, their tacit knowledge about teaching and learning, how they were developed, the effect of these beliefs on learning and professional intervention, and, lastly, how can they be used in their own learning during the course. The author advocates in favor of the adoption of constructivist theories and active methodologies in this field of study. Constructivist teaching is seen as a set of principles of pedagogical intervention derived from several psychological theories, which takes into account the mediating character of people in their own learning.

\section{Conclusion}

The present study identified and analyzed the beliefs of undergraduates, who are studying to receive a Bachelor's degree in Physical Education, on the strategies of how to teach sports (learning tasks and verbal intervention). The set of personal experiences obtained in the context of Physical Education and sports during childhood and youth, especially sports training, founded the participants' beliefs about teaching.

In general, the participants' beliefs on teaching strategies were directed towards primarily using analytical tasks as an elementary way to teach sports, based on the idea of developing technical skills in a progressive way until it can be applied in a formal game. One of the undergraduates primarily used global tasks with modified games, caring for the motivation and fun of learners during learning. Furthermore, others acknowledged synthetic tasks as ways of developing technical and tactical aspects in situations with a reduced number of players, which they found more useful in preparing for competitions.

The belief of teaching sports based on the use of associated analytical tasks, verbal interventions aimed at management, and prescriptive and positive evaluative pedagogical feedbacks, characterizes a particular conceptual model similar to direct teaching models. In the direct teaching model, the teacher or coach established and controls most of the variables involved in the teaching and learning process; a very similar model to those used in sports training.

We also found that these beliefs were constructed with motor sports experiences as central elements of this process. Prolonged exposure of participants to various sports learning situations in youth helps to memorize values, behaviors, and concepts regarding teaching and learning, providing the development of a set of beliefs with some coherence to constitute their own models on how to teach sports. This particular conceptual system and coherent pedagogical behaviors are significant to the undergraduate because its elements (values, feelings, concepts) are also part of the participants' own identity.

The implications of these results fall on initial training programs, especially in the daily teaching practice of teachers instructing teachers. Thus, it is necessary to make learning more meaningful by appreciating the students' previous beliefs or knowledge, and assisting them in transforming the development of their own beliefs. This can be done by creating situations that are authentic or similar to the reality of the future coach or teacher, and also in circumstances that the individual already knows. The reflection and critical analysis of undergraduates on their own beliefs and teaching practices can be useful procedures, and can be done from journals or reflective texts, audio and video recordings of interventions, or discussions with their peers in the classroom.

Therefore, they will be able to help undergraduates understand the process of (re)constructing their beliefs about teaching to evaluate the negative and positive aspects of the models they use and to analyze their most 
significant experiences, their most central beliefs, their epistemological beliefs, their values, and their personal and professional identity.

\section{REFERENCES}

Adamakis, M., \& Zounhia, K. (2016). The impact of occupational socialization on physical education pre-service teachers' beliefs about four important curricular outcomes: A cross-sectional study. European Physical Education Review, 22(3), 279-297.

Alegro, R. C. (2008). Conhecimento prévio e aprendizagem significativa de conceitos históricos no ensino médio. (Doutorado em Educação), Universidade Estadual Paulista Julio de Mesquita Filho, Marília.

Bardin, L. (2011). Análise de conteúdo. Lisboa, Portugal: Edições 70.

Bernstein, E., Herman, A. M., \& Lysniak, U. (2013). Beliefs of pre-service teachers toward competitive activities and the effect on implementation and planning for physical education classes. Teacher Education Quarterly, 40(4), 63-79.

Brasil. (2002). Parecer $n^{\circ}$ CNE/CP 009/2001 de 18 de janeiro de 2002. Dispõe sobre as Diretrizes Curriculares Nacionais para a Formação de Professores da Educação Básica, em nível superior, curso de licenciatura, de graduação plena. Recovered from http://portal.mec.gov.br/cne/arquivos/pdf/009.pdf.

Calderhead, J. (1988). The development of knowledge structures in learning to teach. In J. Calderhead (Ed.), Teachers' professional learning (pp. 51-64). London, England: Falmer Press.

Denzin, N. K., \& Lincoln, Y. S. (2008). O planejamento da pesquisa qualitativa: teorias e abordagens (2 ed.). Porto Alegre, Brazil: Artmed.

Figueiredo, Z. C. C. (2004). Formação docente em Educação Física: experiências sociais e relação com o saber. Movimento, 10(1), 89-112.

Figueiredo, Z. C. C. (2008). Experiências sociocorporais e formação docente em Educação Física. Movimento, 14(1), 85-110.

Figueiredo, Z. C. C. (2010). Experiências profissionais, identidades e formação docente em educação física. Revista Portuguesa de Educação, 23(2), 153-171.

Fives, H., \& Buehl, M. M. (2012). Spring cleaning for the messy construct of teachers' beliefs: What are they? Which have been examined? What can they tell us? In K. R Harris., S. Graham, \& T. Urdan (Eds.), APA Educational Psychology Handbook (pp. 471-499). Washington DC, USA: APA.

Fives, H.., Lacatena, N., \& Gerard, L. (2015). Teachers' beliefs about teaching (and learning). In H. Fives \& M. G. Gill (Eds.), International handbook of research on teachers' beliefs (pp. 37-54). New York, USA: Routledge, Taylor and Francis Group.

Gariglio, J. A. (2011). A socialização pré-profissional de um professor de Educação física: a experiência no universo esportivo em questão. Pensar a Prática, 14(2), 1-10.

Gilbert, W., Côté, J., \& Mallett, C. (2006). Developmental paths and activities of successful sport coaches. International Journal Sports Science \& Coach, 1(1), 69-76.

Gomes, A. P., Dias-Coelho, U. C., Cavalheiro, P. O.., Gonçalvez, C. A. N.., Rôças, G., \& Siqueira-Batista, R. (2008). A educação médica entre mapas e âncoras: a aprendizagem significativa de David Ausubel, em busca da arca perdida. Revista Brasileira de Educação Médica, 32(1), 105-111.

Kagan, D. M. (1992). Professional growth among preservice and Beginning teachers. Rev Educ Res, 62(2), 129-169.

Kulinna, P. H., Brusseau, T., Ferry, M., \& Cothran, D. (2010). Preservice teachers' belief systems towards curricular outcomes for Physical Education. Research Quarterly Exercise and Sport, 81(2), 189-198.

Lodewyck, K. R. (2015). Relations between epistemic beliefs and instructional approaches to teaching games in prospective Physical Educators. The Physical Educator, 72, 677-700.

Maxwell, J. A. (2005). Qualitative research design: an interpretative approach. California: Sage Publications.

Metzler, M. (2000). Instruction Models for Physical Education. Boston: Allyn \& Bacon. 
Moreira, M. A. (2012). ¿Al final qué es aprendizaje significativo? Revista Qurriculum, 25, 29-56.

Ní Chróinín, D., \& O’Sullivan, M. (2016). Elementary classroom teachers' beliefs across time: Learning to teach Physical Education. Journal of Teaching in Physical Education, 35(2), 97-106.

Pajares, M. F. (1992). Teachers' Beliefs and Educational Research: Cleaning Up a Messy Construct. Review of Educational Research, 62(3), 307-332.

Philpot, R., \& Smith, W. (2011). Beginning \& graduating student-teachers' beliefs about physical education: a case study. Asia-Pacific Journal of Health, Sport and Physical Education, 2(1), 33-50.

Posner, G. J., Strike, K. A., Hewson, P. W., \& Gertzog, W. A. (1982). Accommodation of a scientific conception: Toward a theory of conceptual change. Science Education, 66(2), 211-227.

Ramos, V., Souza, J. R., Brasil, V.Z., Barros, T. E. S., \& Nascimento, J. V. (2014). As crenças sobre o ensino dos esportes na formação inicial em Educação Física. Journal of Physical Education 25(2), 231-244.

Randall, L., \& Maeda, J. K. (2010). Pre-service Elementary Generalist Teachers' Past Experiences in Elementary Physical Education and Influence of these Experiences on Current Beliefs. Brock University, 19(2), 20-35.

Richardson, V. (1996). The role of attitudes and beliefs in learning to teach. In J. Sikula (Ed.), The handbook of research in teacher education (pp. 102-119). New York, USA: Macmillan.

Richardson, V. (2003). Pre-service teachers' beliefs. In J. Raths \& A. Mcaninch (Eds.), Teacher beliefs and teacher education. Advances in teacher education (pp. 1-22). Greenwich, England: Information Age Publishers.

Rink, J. (1993). Teaching physical education for learning. St. Louis, USA: Mosby.

Rokeach, M. (1981). Crenças, atitudes e valores: uma teoria de organização em mudança. Rio de Janeiro, Brazil: Interciência.

Saad, M. A. (2002). Estruturação das sessões de treinamento técnico-tático nos escalões de formação do futsal. (Mestrado em Educação Física), Universidade Federal de Santa Catarina, Florianópolis.

Saad, M. A. (2012). A formação técnico-tática de jogadores de futsal nas categorias sub-13 e sub-15: análise do processo de ensino-aprendizagem-treinamento (Doutorado em Educação Física). Universidade Federal de Santa Catarina, Florianópolis.

Sarmento, P. (2004). Pedagogia do desporto e observação. Lisboa, Portugal: FMH Edições.

Siedentop, D. (1998). Aprender a enseñar la Educación Física. Barcelona, España: INDE.

Skott, J. (2015). The promises, problems, and prospects of research on teachers' beliefs. In H. Fives \& M. G. Gill (Eds.), International handbook of research on teachers' beliefs (pp. 37-54). New York, USA: Routledge, Taylor and Francis Group.

Sofo, S., Beard, D. H., Slattery, A., \& Howard, S. (2012). Preservice teachers' beliefs about the curricular goals for physical education. Missouri Association for Health, Physical Education, Recreation and Dance, 22(1), 18-35.

Souza, J. R., Brasil, V.Z., Kuhn, F., Barros, T. E. S., \& Ramos, V. (2017). As crenças de graduandos em Educação Física sobre o ensino dos esportes. Movimento, 23(1), 133-146.

Sparkes, A. C., \& Smith, B. (2014). Qualitative research methods in sport, exercise and health. New York: Routledge.

Stefanello, J. M. F. (1999). A participação da criança no desporto competitivo: uma tentativa de operacionalização e verificação empirica da proposta teórica de Urie Brofenbrenner. (Doutorado em Educação Física), Universidade de Coimbra, Coimbra.

Ticó-Camí, J. (2002). Tareas deportivas en los deportes colectivos: Una aplicación al baloncesto. In S. Ibañez \& M. Macías-García (Eds.), Novos horizontes para o treino do basquetebol (pp. 87-110). Lisboa: Faculdade de Motricidade Humana, Universidade Técnica de Lisboa.

Tsangaridou, N. (2006). Teachers' beliefs. In D. Kirk, D. MacDonald \& M. O'Sullivan (Eds.), The handbook of physical education (pp. 486-501). London, England: SAGE.

Tsangaridou, N. (2008). Trainee primary teachers' beliefs and practices about physical education during student teaching. Physical Education and Sport Pedagogy, 13(2), 131-152.

Yin, R. K. (2010). Estudo de caso: Planejamento e Métodos. Porto Alegre, Brazil: Bookman. 